\title{
Multi-Sector Collaboration in Legal Protection for Teachers and Students Amidst of Covid-19 Pandemic (Case of Mirit Kebumen, Indonesia)
}

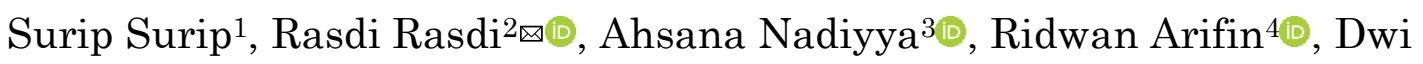
Bagus Kurniawan 5

1 Persatuan Guru Republik Indonesia Kecamatan Mirit, Kebumen 2,3,4,5 Faculty of Law, Universitas Negeri Semarang, Indonesia

Corresponding author: mr.rasdi@mail.unnes.ac.id

Abstract: The Covid-19 pandemic has become one of the most unexpected problems and has had a significant impact on all sectors. Not only the health sector, but also education. The pandemic is forcing all parties to change the pattern and method of education, as well as forcing them to adapt quickly. Various learning process activities are carried out online, but various research results show the weaknesses of this method. Starting from the effectiveness of the learning process, dependence on communication devices (cell phones and laptops), to various legal problems faced by teachers, students, and parents of students. This service program aims to provide reinforcement in terms of protection for teachers and students during the pandemic by involving multisectors (Universities-Legal Aid Institutions-Teachers' Union). The partner in this activity is the Indonesian Teachers Association (PGRI) in Mirit District, Kebumen Regency, Central Java. The implementation method in this service uses several things, namely: (1) socialization, (2) education, (3) legal assistance, (4) partner networks. Through this service program, it is hoped that in addition to realizing collaboration between institutions: the Faculty of Law UNNES-LBH-PGRI, it is also hoped that this activity can provide encouragement for teachers in increasing the capacity of legal assistance.

Keywords: legal protection; collaboration; education policy

How to cite:

Surip, S., Rasdi, R., Nadiyya, A., Arifin, R., \& Kurniawan, D. B. (2021). Multi-Sector Collaboration in Legal Protection for Teachers and Students Amidst of Covid-19 Pandemic (Case of Mirit Kebumen, Indonesia). Indonesian Journal of Advocacy and Legal Services, 3(2), 155-182. https://doi.org/10.15294/ijals.v3i2.50699 


\section{A. Introduction}

The education sector is one of the sectors affected by the Covid-19 pandemic, not only changes in behavior patterns, but various studies also criticize the effectiveness of learning and the rule of law. The rule of law policy in the education sector during the Covid-19 pandemic is the main key to the success of teachers, students, and parents in dealing with changing conditions. In addition to the positive impact of these conditions, ranging from increasing technological awareness of students, teachers, and parents to collaboration between parents and teachers in the teaching and learning process, the education sector is more challenged and changes rapidly than conventional patterns (face to face in the classroom, one-to-one). direction, and less innovative) become more modern with learning innovation, role collaboration, and the use of technology ${ }^{1}$.

However, COVID-19 has also had a significant impact (negative impact) on the education sector. Starting from the findings of several studies that show low student learning outcomes, decreased student motivation and character, to various phenomena of domestic violence due to the online learning process. ${ }^{2}$. In fact, education is important in character building. Law of the Republic of Indonesia Number 20 of 2003 concerning the National Education System, education is defined as a conscious and planned effort to create a learning atmosphere and learning process so that students actively develop their potential to have religious spiritual strength, self-control, personality, intelligence, morals noble values, as well as the skills needed by the community, nation and state. Education is a process in order to influence students so that they can adapt as best they can to their environment and thus will cause changes in themselves that allow them to function in

1 Wahyu Aji Fatma Dewi, "The Impact of COVID-19 on the Implementation of Online Learning in Elementary Schools," Educational: Jurnal Ilmu Pendidikan 2, no. 1 (2020): 55-61, https://doi.org/10.31004/edukatif.v2i1.89; Dian Ratu, Ayu Uswatun, and Hascaryo Pramudibyanto, "Education During the Covid-19 Pandemic," Journal of Sinesthesia 10, no. 1 (2020): 41-48, https://sinestesia.librar.my.id/journal/article/view/44; Dindin Jamaluddin et al., "Online Learning During the Covid-19 Pandemic Period for Prospective Teachers: Barriers, Solutions and Projections," Scientific Paper at UIN Sunan Gunung Djjati Bandung, 2020, 1-10, http://digilib.uinsgd.ac. id/30518/; Alwazir Abdusshomad, "The Influence of Covid-19 on the Implementation of Character Education and Islamic Education," QALAMUNA: Journal of Education, Social and Religion 12, no. 2 (2020): 10715, https://doi.org/10.37680/qalamuna.v12i2.407; Matdio Siahaan, "The Impact of the Covid-19 Pandemic on the World of Education," Journal of Scientific Studies 1, no. 1 (2020): 73-80, https://doi.org/10.31599/jki.v1i1.265.

2 Nelvitia Purba et al., "Efforts to Protect Violence in the Households during Covid-19 in Indonesia," International Journal of Criminology and Sociology 10 (2021): 548-53. 
community life. So, in this effort, the role of the teacher becomes very important ${ }^{3}$.

Various policies in the education sector in dealing with COVID-19 were also implemented, where basically, the principle of education policy during the Covid-19 Pandemic is to prioritize the health and safety of students, educators, education staff, families, and society in general, and consider growth and development. students and psychosocial conditions in an effort to fulfil educational services during the Covid-19 pandemic ${ }^{4}$. However, the decision of the Ministry of Education and Culture raises various pros and cons in society, especially the lack of technology knowledge of students, teachers and parents regarding the application of this online method. Even though teachers must enrich and upgrade their knowledge, being asked to master various applications that support online learning quickly is not as easy as one might think. Likewise with students, maybe for junior high school, high school / vocational students learning and mastering this online application can quickly be done. However, for elementary school students, this is quite difficult to do. Finally, like it or not, parents are asked to be involved in this online learning. Parents with higher education backgrounds will easily adapt. While parents with low educational background, they will just give up if for weeks and they cannot follow the learning process and do not even get a grade at all. There are even students who are constrained by not having adequate communication tools due to the economic conditions of poor families. ${ }^{5}$

3 Tri Rezki Andika Panjaitan, Mahzaniar Mahzaniar, and Herlina Hanum, "Juridical Review on Legal Protection for Teachers Regarding Punishment Actions for Efforts to Discipline Students (Case Study of SD 117513 Pulo Tarutung)," Proceedings of the National Seminar and Expo of Research and Service Results Society 2, no. 1 (2019): 14048; Ridwan Arifin, Rasdi Rasdi, and Riska Alkadri, "An Overview of Law Enforcement Issues and the Fulfillment of Rights in the Context of Universalism and Human Rights Relativism in Indonesia," Legal Scientific Journal LEGALITY 26, no. 1 (2018): 17, https://doi.org/10.22219/jihl.v26i1.6612; Harpani Matnuh, "Legal Protection of Teacher Professionalism," Journal of Citizenship Education 7, no. 2 (2017): 46-50; Ria Widarsih and Nahiyah Jaidi Faraz, "Evaluation of Junior High School Social Studies Teacher Performance Based on Teacher Competency Standards in Kebumen Regency," Social Harmony: Social Studies Education Journal 3, no. 2 (2016): 177-87, online: http://journal.uny.ac.id/index.php/hsjpi\%0AEVALUASI; Ikbal Barlian, "Important Teaching and Learning Strategy," Journal of Social Forum 6, no. 1 (2013): 241-46.

4 Dewi, "Dampak COVID-19 Terhadap Implementasi Pembelajaran Daring Di Sekolah Dasar"; Ratu, Uswatun, and Pramudibyanto, "Pendidikan Dalam Masa Pandemi Covid19"; Siahaan, "Dampak Pandemi Covid-19 Terhadap Dunia Pendidikan"; Widya Sari, Andi Muhammad Rifki, and Mila Karmila, "Pembelajaran Jarak Jauh Pada Masa Darurat Covid 19," Jurnal MAPPESONA, no. 1 (2020): 12.

5 Rahman Hasima, "Perlindungan Hukum Terhadap Guru Dalam Penyelenggaraan Pendidikan Di Kota Kendari," Jurnal Ilmu Hukum Fakultas Hukum Universitas Riau 9, no. 2 (2020): 190-209; Ratu, Uswatun, and Pramudibyanto, "Pendidikan Dalam Masa Pandemi Covid-19"; Yenny Aman Serah and Rini Setiawati, "Non-Penal Policy Against 
Therefore, in dealing with various problems that exist during the learning process during the COVID-19 pandemic, mentoring for teachers and students is important. Not only assistance in the learning and teaching process but also legal assistance to deal with various legal problems that arise during the online teaching and learning process. ${ }^{6}$

The problem of online learning is not only faced by teachers and students, but also parents of students. In the early stages of the initial data survey conducted by the Proposing Team, it was found that several problems faced by partners were as follows:

1) The capacity of human resources in online learning, including:

a) The technology gap between teachers, students and parents in the online learning process;

b) Online learning methods that are deemed ineffective in testing students' abilities; and

c) The role of parents is not optimal because the majority of parents work as farmers and in the fields.

2) Facilities and infrastructure during online learning, including:

a) Availability of electronic devices (cell phones or laptops) in online learning for teachers and students;

b) Limited signal or telecommunications network;

c) The health of students and teachers during the online learning process; and

d) Limitations of innovative methods in online learning.

3) Legal assistance and counselling for teachers, students and parents, including:

a) The unavailability of legal assistance for teachers and students in solving problems during the online learning process;

b) The absence of teacher legal aid institutions for legal assistance;

c) Inadequate information for teachers, students, and parents in solving problems during the online learning process; and

d) The absence of multi-sector collaboration involving non-governmental organizations and universities in optimizing online learning and mentoring for teachers and students.

Teacher Criminalization," Journal of Critical Reviews 7, no. 14 (2020): 656-60, https://doi.org/10.31838/jcr.07.14.115.

6 Jamaluddin et al., "Pembelajaran Daring Masa Pandemik Covid-19 Pada Calon Guru: Hambatan, Solusi Dan Proyeksi"; Brian A. Jacob, "The Effect of Employment Protection on Teacher Effort," Journal of Labor Economics 31, no. 4 (2013): 727-61, https://doi.org/10.1086/669942; Yenny Serah and Rini Setiawati, "Fulfillment of Teacher Protection Rights," Annual Program of International Conference on Human Rights 1, no. 1 (2019): 1-10. 
The problems faced by these partners, through this service, they are able to provide several related solutions, including:

1) Provide and introduce legal assistance for teachers and students in Kebumen Regency.

2) Equip teachers in improving legal counselling skills for students during online learning.

3) Providing legal assistance capacity strengthening for teachers and students through multi-sector collaboration.

4) Provide a forum for teachers and students related to solving problems related to law during the online learning process.

5) Provide regular and continuous training for teachers and students in increasing their capacity both related to the teaching and learning process and other supporting capacities.

\section{B. Literature Review}

\section{Legal Protection Theory}

Legal protection is the right of everyone, regardless of the work and profession they carry out. Legal protection is a constitutional right of every person. This is clearly stated in Article 28D paragraph (1) of the 1945 Constitution which reads, "Everyone has the right to recognition, guarantee, protection and fair legal certainty and equal treatment before the law.

As mandated in the 1945 Constitution Article 31 paragraph (3) which reads: "The government seeks and organizes a national education system that increases faith and piety and noble character in the context of educating the nation's life," and paragraph (5) which reads: "The government advances science knowledge and technology by upholding religious values and national unity for the advancement of civilization and the welfare of mankind."

According to CST Kansil Legal Protection are various legal efforts that must be provided by law enforcement officers to provide a sense of security, both mentally and physically from disturbances and various threats from any party. ${ }^{7}$ Protection in a simple sense can be interpreted as an effort to gain a sense of security, kept away from threats, calamity and fear. Thus, legal protection for teachers can be interpreted as protection provided by law to

7 Hasnawi Haris and Herman, "Development of a Protection Model for Teachers as Professional Educators in the Indonesian Legal System" 473, no. Icss (2020): 759-62, https://doi.org/10.2991/assehr.k.201014.164; Serah and Setiawati, "Fulfillment of Teacher Protection Rights"; R. Arifin, "Legal Protection and Law Enforcement: The Unfinished Works," Indonesian Journal of Advocacy and Legal Services 2, no. 1 (2020): 1-4; Yenny Serah and R Setiawati, "Urgency Formation of Legal Service Institutions and Teacher Protection,” 2020, 1-8, https://doi.org/10.4108/eai.26-11-2019.2295209. 
teachers, from various threats of violence, threats, discriminatory treatment, intimidation and unfair treatment.

In Article 39 Paragraph 1 of PP No. 74 of 2008 it is stated that "Teachers have the freedom to give sanctions to their students who violate religious norms, moral norms, norms of decency, written and unwritten regulations set by the teacher, education unit level regulations, and statutory regulations. invitation in the learning process which is under his authority."8

Meanwhile, Article 39 Paragraph 2 of PP No. 74 of 2008 states that sanctions can be in the form of reprimands and/or warnings, both oral and written, as well as educative punishments in accordance with educational rules, teacher code of ethics, and laws and regulations. Violations of educational unit regulations committed by students whose sanctions are beyond the authority of the teacher, are reported by the teacher to the education unit leader. Violations of laws and regulations committed by students are reported by the teacher to the leader of the education unit to be followed up in accordance with the provisions of the legislation.

Furthermore, Article 40 of Government Regulation No. 74 of 2008 states that teachers are entitled to protection in carrying out their duties in the form of a sense of security and safety guarantees from the Government, Regional Governments, educational units, Teacher Professional Organizations, and/or the Community in accordance with their respective authorities. A sense of security and guarantee of safety in carrying out their duties is obtained by the teacher through the protection of: $a$. law; $b$. profession; and c. occupational safety and health. Community, Teacher Professional Organizations, Government or Local Governments can help each other in providing protection.

Basically, the protection against acts as detailed above, is not limited to the capacity as a teacher, but also in his status as a citizen, such protection is an obligation of the state to its citizens. Indonesia is a state of law, this is clearly stated in the 1945 Constitution. One of the elements of a state of law is the guarantee of human rights and equality before the law. This has been formulated in detail in Articles 28A to 28J of the 1945 Constitution.

The solution to every legal problem lies in how the law enforcement process is carried out. Law enforcement is the process of making efforts to enforce or actually function legal norms as guidelines for behavior in traffic or legal relationships in social and state life.

8 Dwi Sulisworo, Rahmad Nasir, and Ika Maryani, "Identification of Teachers' Problems in Indonesia on Facing Global Community," International Journal of Research Studies in Education 6, no. 2 (2016), https://doi.org/10.5861/ijrse.2016.1519. 
Juridically, the Law on the Protection of Teachers and Lecturers has been contained in Law No. 14 of 2005. This is clearly seen in Chapter VII article 39 which states that teachers are entitled to protection in carrying out their duties in the form of a sense of security and safety guarantees from the Government, Regional Government, education units, Teacher Professional Organizations, and/or the Community in accordance with their respective authorities.

Departing from the explanation above, it can be seen that the existence of Law No. 14 of 2005 has contained protection for teachers for their profession. However, the implementation of the Law has not yet been implemented. The law is mostly highlighted as a legal force for improving the welfare of teachers/lecturers, while the protection of the profession of teachers/lecturers is often overlooked.

Legal protection of teachers in their profession, in some studies confirmed that as a profession, in working teachers need guarantees and protection of certain laws and regulations. This is very important so that in addition to getting a sense of security, they also have clarity about their rights and obligations, what they can and cannot do, and what other parties can and cannot do to them, both as human beings, educators, and workers. ${ }^{9}$

As educators, teachers are often in a dilemmatic position, between the demands of the profession and the treatment of society. Teachers are required to be able to deliver students to achieve educational goals. However, the teacher's efforts to enforce discipline, teachers collided with the Child Protection Act and the Indonesian Child Protection Commission (KPAI). If teachers fail to enforce the discipline of their students and fail to deliver students to the achievement of educational goals, the educator will again become a target for these failures.

When teachers want to punish their students in order to enforce discipline, then spontaneously parents and the community categorize it as an act of violating human rights and Law Number 35 of 2014 concerning Child Protection. They then report the teacher's actions to the police or to KPAI. Due to the existence of KPAI and Law Number 35 of 2014 concerning Child

9 Serah and Setiawati, "Non-Penal Policy Against Teacher Criminalization"; Serah and Setiawati, "Urgency Formation of Legal Service Institutions and Teacher Protection"; Panjaitan, Mahzaniar, and Hanum, "Tinjauan Yuridis Tentang Perlindungan Hukum Bagi Guru Terkait Tindakan Pemberian Hukuman (Punishment) Terhadap Upaya Mendisiplinkan Siswanya (Studi Kasus SD 117513 Pulo Tarutung)"; Fokky Fuad, Istiqomah Istiqomah, and Suparji Achmad, "Dialektika Perlindungan Hukum Bagi Guru Dalam Mendisiplinkan Siswa Di Sekolah," Indonesian Journal of Law and Policy Studies 1, no. 1 (2020): 55, https://doi.org/10.31000/ijlp.v1i1.2634; Endang Komara, "Perlindungan Profesi Guru Di Indonesia," Mimbar Pendidikan 1, no. 2 (2016): 151, https://doi.org/10.17509/mimbardik.v1i2.3938. 
Protection, the existence of teachers is in a very passive position and becomes a figure that is awry.

One example of a case, in 2015 ago there was a criminalization case that befell the teacher profession. A teacher named Raden Darajat Imandi who lives in Subang, West Java, was questioned by investigators from the Subang Police on suspicion of neglecting his student when another student was pinched. The public reacted strongly to the news. In addition, there are also many other similar cases in Central Java.

The public considered that in the past, if students complained to their parents because they were sanctioned by the teacher, they would be scolded or even given additional punishment by their parents. This is different from the current situation, where parents defend their children fiercely and even report teachers who give sanctions to the authorities.

Even though Law Number 14 of 2005 concerning teachers and lecturers has explicitly protected the teaching profession and lecturers, in the field of implementation the power of the Act still does not appear to contribute to the fate of teachers/lecturers as educators. For this reason, it is time and place for teachers/lecturers to build the power of solidarity to encourage the government to improve the working conditions of teachers and protect their profession with clear legal force.

Law number 14 of 2005 concerning Teachers and Lecturers as a whole is basically a guarantee and protection for teachers and lecturers in carrying out their profession. One of the rights of teachers is the right to obtain protection in carrying out their duties and intellectual property rights. In Article 39 of Law Number 14 of 2005 concerning Teachers and Lecturers, Section 7 concerning Protection, it is stated that many parties are obliged to provide protection to teachers, the following areas of protection are as follows. 1. The government, local government, community, professional organizations, and/or education units are obliged to provide protection to teachers in carrying out their duties.

2. The protection includes legal protection, professional protection and occupational safety and health protection.

3. Legal protection includes protection against acts of violence, threats, discriminatory, discriminatory, intimidating or unfair treatment on the part of students, parents of students, society, bureaucracy or other parties.

4. Professional protection includes protection against layoffs that are not in accordance with statutory regulations, unreasonable rewards, restrictions on expressing views, harassment of the profession and other 
restrictions/prohibitions that can hinder teachers from carrying out their duties.

5. Occupational safety and health protection includes protection against the risk of work security disturbances, work accidents, fires at work, natural disasters, occupational health and/or other risks.

Based on the mandate of Article 39 of Law Number 14 of 2005 concerning Teachers and Lecturers as mentioned above, it can be stated that the realm of legal protection for teachers covers all dimensions related to efforts to realize legal certainty, health, safety, and comfort for teachers in carrying out their professional duties. .

The presence of regulations governing the protection of the teaching profession has become an urgent demand to be realized. In order for the education process to be good and teachers carry out their duties professionally, the role of the central and local government as well as the community is needed in order to create teachers who have dignity and are protected by law in carrying out their profession in order to create maximum quality achievement, this is in accordance with the mandate of Law No. 20 of 2003 concerning the National Education System (Sisdiknas). ${ }^{10}$

Law on teachers and lecturers is really needed to complement Law No. 20 of 2003 concerning the National Education System. Article 39 Paragraph (2) of Law Number 20 of 2003 concerning the National Education System states that educators are professionals. Position teacher and lecturers as professionals aim to implement the national education system and realize the goals of national education, namely the development of the potential of students to become human beings who believe and fear God Almighty, have noble character, are healthy, knowledgeable, capable, creative, independent, and become democratic and responsible citizens.

The position of teachers as professionals serves to increase the dignity of teachers and their role as learning agents to improve the quality of national education. In line with this function, the position of teachers as professionals aims to implement the national education system and realize the goals of national education, namely the development of the potential of students to become human beings who believe and fear God Almighty, have noble character, are healthy, knowledgeable, capable, creative, be independent, and become a democratic and responsible citizen.

\section{Legal Aid Concept}

10 Jamaluddin et al., "Pembelajaran Daring Masa Pandemik Covid-19 Pada Calon Guru: Hambatan, Solusi Dan Proyeksi"; Sulisworo, Nasir, and Maryani, "Identification of Teachers' Problems in Indonesia on Facing Global Community.” 
Basically, legal aid comes from the word "assistance" in the Big Indonesian Dictionary (KBBI) which means help or support, namely help without expecting anything in return. The word "law" contains the overall meaning of rules or norms, values as instructions or guidelines regarding an aspect of community life with a view to creating coercive peace to protect human interests in society.

The term legal aid in Indonesia can be said to be a new thing compared to western countries. Indonesian people only knew him around the seventies. The concept and idea of legal aid in Indonesia is essentially inseparable from the current development of legal aid in developed countries. Providing an understanding or formulating a definition of legal aid is not an easy matter because the complexity of the problem is not only regarding the law and the development of the community but also regarding the existence and program of legal aid itself.

Despite the various complexities referred to above, the definition of legal aid itself is found in various laws and according to experts.

\section{1) Definition of Legal Aid in Legislation}

a) Law Number 8 of 1981 concerning the Criminal Procedure Code Not a single article in the Criminal Procedure Code (KUHAP) provides a definition of legal aid, but the term providing legal aid in the Criminal Procedure Code is only a legal basis for the poor (poor) who are having problems in the criminal law area. The KUHAP only mentions a little about legal aid, the thing that is mentioned about legal aid regulated in the KUHAP is only about the condition of how the suspect or defendant gets legal assistance and does not explain clearly what exactly is meant by legal aid in the KUHAP itself. At a glance, the definition of legal aid is stated in Article 1 point 13 which reads: A legal advisor is a person who meets the requirements determined by or based on the law to provide legal assistance. ${ }^{11}$

If this understanding is used, it means that the legal aid referred to in the Criminal Procedure Code includes the provision of professional and formal legal assistance, namely in the form of providing legal aid services for everyone who is in a criminal case. From the understanding contained in Article 1 point 13, it implies that the

11 Suwari Akhmaddhian, "Bantuan Hukum Bagi Tenaga Pendidik Dan Kependidikan Di Desa Mancagar Kabupaten Kuningan, Indonesia," Empowerment: Jurnal Pengabdian Masyarakat 1, no. 1 (2018): 72-78; Fachrizal Afandi, "Implementasi Pengabdian Masyarakat Berbasis Access To Justice Pada Lembaga Bantuan Hukum Kampus Negeri Pasca Pemberlakuan Undang-Undang Bantuan Hukum," Jurnal Rechts Vinding: Media $\begin{array}{llllll}\text { Pembinaan Hukum Nasional 2, no. } 1 & \text { (2013): } & 31 \text {, }\end{array}$ https://doi.org/10.33331/rechtsvinding.v2i1.80. 
guarantee of providing free legal aid has not been fully regulated. Although further explanation is in the following articles, a glimpse of legal aid in the Criminal Procedure Code as regulated in articles 5412 to 65 of the Criminal Procedure Code only emphasizes the right of a suspect or defendant to obtain legal assistance from a legal advisor or more during and during the examination stage.

b) Law Number 18 of 2003 concerning Advocates Article 1 Number 9

The Law on Advocates states that Legal Aid is a legal service provided by Advocates free of charge to clients who cannot afford it.

c) Law Number 16 of 2011 concerning Legal Aid

Article 1 point 1 of the Law on Legal Aid states that Legal Aid is a legal service provided by the Legal Aid Provider free of charge to the Legal Aid Recipient.

d) Government Regulation Number 42 of 2013 concerning Terms and Procedures

Provision of Legal Aid and Distribution of Legal Aid Funds, in article 1 point 1 states that Legal Aid is legal services provided by Legal Aid Providers free of charge to Legal Aid Recipients.

e) Permenkumham Number 3 of 2013 concerning Procedures for Verification and Accreditation of Legal Aid Institutions or Community Organizations and Minister of Law and Human Rights Number 1 of 2018 concerning Paralegals in Providing Legal Aid.

The two Permenkumham above provide the same understanding of legal aid, namely legal aid is legal services provided by legal aid providers free of charge to legal aid recipients. For Legal Aid Recipients as stipulated in the regulation above, what is meant by Legal Aid Recipients are poor people or groups of people which include every person or group of poor people who cannot fulfill their basic rights properly and independently. The basic rights referred to include, among others: the right to food, clothing, health services, education services, employment and business, and/or housing.

\section{2) Understanding Legal Aid According to Experts}

Legal Aid is an effort to help people who are not capable in the legal field. In a narrow sense, legal aid is legal services provided free of charge to underprivileged clients. Legal aid in a broader sense can be interpreted as an effort to help disadvantaged groups in the legal field. In this broader sense, according to Nasution this effort has three interrelated aspects, namely: aspects of formulating legal rules; aspects 
of supervision of the mechanism to keep the rules to be obeyed; and aspects of public education so that the rules are lived up. ${ }^{12}$

From Adnan Buyung Nasution's thoughts, there are at least two important things related to legal aid in a broad sense ${ }^{13}$, first it is a movement to increase public legal awareness so that people will realize their rights and obligations as human beings and as citizens. citizen of the Republic of Indonesia. second, legal aid also means efforts to make legal improvements so that the law can meet the needs of the people and keep up with changing circumstances. The author himself agrees with the three aspects put forward by Adnan Buyung Nasution, because it is very dangerous if the legislators are of the opinion that the current legal regulations are perfect and sufficient to cope with all the needs of the poor in providing legal aid.

\section{Basic Theory and Concepts of Human Rights}

Human rights are said to be human rights are rights that human beings possess because they are human beings. ${ }^{14}$ As an identity that distinguishes humans from other creatures, it is appropriate that human rights (HAM) are universally recognized regardless of skin color, gender, age, cultural background and also religion or spiritual beliefs.

In line with the above opinion, Asshidiqieemphasized that human rights as rights inherent in humans because of the nature and nature of

12 Muhammad Ikhsan Lubis, "The Relationship of International Human Rights Law with International Humanitarian Law in Situations of International Armed Conflicts" 1, no. 01 (2016): 13-34; Imron Fauzi, "Dinamika Kekerasan Antara Guru Dan Siswa: Studi Fenomenologi Tentang Resistensi Antara Perlindungan Guru Dan Perlindungan Anak," Tarbiyatuna: Jurnal Pendidikan Islam 10, no. 2 (2017): 40-69.

13 Hasima, "Perlindungan Hukum Terhadap Guru Dalam Penyelenggaraan Pendidikan Di Kota Kendari."

14 Sri Rahayu Wilujeng, "Hak Asasi Manusia: Tinjauan Dari Aspek Historis Dan Yuridis," Jurnal Humanika 18, no. 2 (2013): 162; Susani Triwahyuningsih, "Perlindungan Dan Penegakan Hak Asasi Manusia (HAM) Di Indonesia," Jurnal Hukum Legal Standing 2, no. 2 (2018): 133-121, https://doi.org/http://dx.doi.org/10.24269/ls.v2i2.1242.; Udiyo Basuki, "Perindungan HAM Dalam Negara Hukum Indonesia: Studi Ratifikasi Konvensi Hak-Hak Disabilitas (Convention on The Rights of Persons with Disabilities)," SosioReligia 10, no. 1 (2012): 17-34, https://www.aifisdigilib.com/uploads/1/3/4/6/13465004/revisi_no_02._perlindungan_hak_asasi_manusia_p enulis_udiyo_basuki.pdf; Zainal Abidin, "Perlindungan Hak Asasi Manusia Di Indonesia," Makalah Pelatihan HAM Bagi Panitia RANHAM Prov. Sumatera Barat, Padang, 13 Juni 2013 (Jakarta, 2013), https://referensi.elsam.or.id/wp-content/uploads/2014/09/21.Perlindungan-Hak-Asasi-Manusia-di-Indonesia.pdf; Eko Hidayat, "Perlindungan Hak Asasi Manusia Di Indonesia Dalam Negara Hukum," ASAS: Jurnal Hukum Ekonomi Syariah 8, no. 2 (2016): 1-8, https://doi.org/https://doi.org/10.24042/asas.v8i2.1249; Arifin, Rasdi, and Alkadri, "Tinjauan Atas Permasalahan Penegakan Hukum Dan Pemenuhan Hak Dalam Konteks Universalime Dan Relativisme Hak Asasi Manusia Di Indonesia.” 
human birth as human beings. ${ }^{15}$ It is said to be 'inherent' or 'inherent' because these rights are owned due to the nature of his birth as a human being and not because of a gift from any power organization including the state. It is also said to be 'attached', so basically these rights cannot be taken away or revoked for a moment.

The origin of the idea of human rights can be traced back as far back as ancient times with Stoic philosophy to modern times. Among legal experts, there are three main theories that explain the origin of the thought of human rights, namely natural law theory, positivism, and anti-utilitarianism, as follows.

\section{1) Natural Law Theory}

The thought which later gave birth to the theory of natural law could not be separated from the influence of the writings of Saint Thomas Aquinas. According to Aquinas, natural law is part of God's law that can be known through human reasoning. Aquinas's ideas lay the foundations for autonomous individual rights. Every human being is given a unique individual identity by God, and this is separated by the State. However, Aquinas's idea has been criticized because it is not empirical, how do we know God has given certain rights to everyone.

Hugo de Groot, or as he is known as Grotius, further developed Aquinas' theory of natural law by breaking its theistic origins and making it a product of rational secular thought. According to Grotius, the existence of natural law can be known by using correct reasoning, and the degree of its validity does not depend on God. Natural law which is the basis of positive law or written law, can be rationalized by using axial logic and geometry. Throughout the 17th century, Grotius' views continued to be refined. Through this theory, subjective individual rights are accepted and recognized. ${ }^{16}$

The figures who are considered the most instrumental in laying the foundations of natural law theory are John Locke and JJ Rousseau. In his classic book: "The Second Treaties of Civil Government and a Letter Concerning Toleration", John Locke put forward a postulation of the idea that all individuals are endowed by nature with inherent rights to life, liberty and property, which are their own and cannot be revoked or stripped down by the State. Through a social contract, the protection of this inalienable right is left to the State. If the ruler of the State ignores the social contract by violating the natural rights of individuals, then the people in that State are free to take

15 Jimly Asshiddiqie, "Pancasila Dan Empat Pilar Kehidupan Berbangsa," 2019.

16 Lael K Weis, "Constitutional Directive Principles," Oxford Journal of Legal Studies 37, no. 4 (2017): 916-45, https://doi.org/10.1093/ojls/gqx015. 
down the ruler and replace him with a government that is willing to respect these rights.

Rousseau followed the social contract theory. But unlike Locke, Rousseau said that natural law does not create individual natural rights, but the sovereign rights of citizens as a unit. Every right that is derived from a natural law will exist in the citizen as a unit that can be identified through the general will. It was Locke's idea of natural rights that underlies the emergence of the rights revolution in the British, United States and French revolutions of the 17 th and 18 th centuries.

Natural law theory sees human rights born from God as part of human nature. When humans are born, they are inherent in a number of rights that cannot be replaced or removed, regardless of their religious background, ethnicity, social class, and sexual orientation.

\section{2) Positivism or Utilitarian Theory}

The idea of human rights based on the view of natural law was seriously challenged in the 19th century. It was Edmund Burke, an Irish national who was troubled by the French Revolution, who propagated the "terrible idea of human equality". Burke alleges that the compilers of the "Declaration of the Right of Man and of the Citizen" are untrue ideas and vain hopes in humans who are destined to live an unclear life with difficulty. ${ }^{17}$

Hume, a Scottish philosopher, held the view that the theory of natural law mixes between what is (is) and what ought to be (ought). What exists are facts that can be proven empirically and can be verified. Here one cannot argue right or wrong, because its existence can be proven and tested empirically. Meanwhile, what should be (ought) is the principle of morality, namely the objective reality that cannot be proven. In morality people can argue right or wrong. According to Hume, the law must clearly separate what exists from morality. Natural law theory is only in the area of morality and does not depart from the formal legal system.

In the view of positivism theory, rights only exist if there is a law that regulates them. Morality must also be clearly separated in the legal dimension. The ownership rights of each individual can be enjoyed if it is officially granted by the authorities or the state. And the most prominent in this view is to prioritize the welfare of the majority. Meanwhile, minority

17 Raed SA Faqir, "The Philosophy of Punishment : A Study to the History of Classical and Positive Schools of Penology," Forensic Research \& Criminology International Journal 1, no. 6 (2015): 4-11, https://doi.org/10.15406/frcij.2015.01.00035; Chloë Kennedy, "Declaring Crimes," Oxford Journal of Legal Studies 37, no. 4 (2017): 741-69, https://doi.org/10.1093/ojls/gqx005. 
groups whose preferences are not represented by the majority can be ignored and lose their rights.

\section{3) Theory of Justice}

The theory of justice was born from a critique of the theory of positivism. The figures who developed this theory were Ronald Drowkin and John Rawls. Drowkin's theory is very much based on the obligation to treat its citizens equally which is carried out by the State. Of course, moral values, power, or using other grounds as an excuse to override human rights-except the principle of equal treatment itself. Therefore, human rights are intended as a bulwark or trump in terms that are used by themselves or individuals against the will of the public which are detrimental, or which make them not receive the same treatment. But not all rights have a Trump nature can be used as a bulwark against the will of the public. Rights groups that fall into this group are non-human rights_rights that are not fundamental. Example, the right to establish a residence somewhere. Rights like this can be violated by the government but if it is based on the reason that there is a greater public interest.

Another idea is the view of John Rawls who later introduced the concept of distributive justice. There are two important things in this case, namely fairness and equality. First, everyone has the same right to the broadest basic liberties, as broad as the same freedoms for all. Second, economic and social inequalities must be regulated in such a way as to produce the maximum benefit for those who are most disadvantaged and provide a system of equal access and equal opportunities. According to Rawls, in society, every individual has the same rights and freedoms. But these rights and freedoms are often not enjoyed equally - for example, the right for everyone to get an education, but this right cannot be enjoyed by everyone because of poverty. To overcome this, Rawls introduced the difference principle. This principle states that equitable distribution of resources should be prioritized, unless it can be proven that an unequal distribution will make the situation of disadvantaged people better. ${ }^{18}$

In Rawls's view, everyone has rights that are based on the concept of justice that is non-negotiable, even related to the issue of public welfare in general. For this reason, justice will be realized if it is based on the principles and positions of their respective origins. In this situation each person will be assumed to choose two basic principles of justice. The first principle is that everyone will be given equal rights. The second principle is equality which is

18 Faqir, "The Philosophy of Punishment: A Study to the History of Classical and Positive Schools of Penology"; Kennedy, "Declaring Crimes." 
based on fair competition and is only justified when it benefits the most disadvantaged party. If there is a conflict between the two, equal freedom must be won from equal opportunities. ${ }^{19}$

\section{4) Theory The Work of Law in Society}

Law as a means of social integration, it will not be possible to work in a vacuum. According to Harry C. Bredemeier, when law works in a social order, it will always get input from other fields such as economics, politics, and culture. The inputs received by the law become inputs and outputs that are returned to society. ${ }^{20}$ Harry C. Bredemeier further said that that is why law in reality functions as a factor in integrating society, so the law must be able to resolve conflicts in an orderly manner, as Bredemeier said: "The law function of the last is the orderly resolution of conflict".

In principle, the law-making process takes place in four major stages, namely the initiation stage, the socio-political stage and the juridical stage, and the dissemination or dissemination stage. First, the initiation stage is the stage that marks the birth or emergence of an idea in society. Second, the activities that take place at this socio-political stage begin with processing, discussing, criticizing, defending the initial ideas that come from the community through the exchange of opinions between various groups and forces in society. Third, the juridical stage is the final stage where the idea is elaborated or formulated furthermore technically into legal provisions, including setting legal sanctions. The fourth stage is the dissemination or dissemination stage. is the socialization stage of a legal product. The end result of the entire law-making process as described above is closely related to the typology of the society in which the law is made and enforced. Chambliss and Seidman make a legal distinction according to "a typology of society based on consensus on values" and "a typology of conflict-based society".

According to Robert B. Seidman and William J. Chambliss, that the process of working the law is largely determined by four main components, namely law-making institutions (laws), law enforcement bureaucracies, role holders, and the influence of personal and social forces. The first three

19 Rawls. John, A Theory Of Justive (Cambridge: The Belknap Press, 1973); Muhammad Hashim Kamali, Freedom, Equality And Justice In Islam (Cambridge: The Islamic Text Society, 1999); Suwardi Sagama, "Analisis Konsep Keadilan, Kepastian Hukum Dan Kemanfaatan Dalam Pengelolaan Lingkungan," Mazahib 15, no. 1 (2016): 20-41, https://doi.org/10.21093/mj.v15i1.590.

20 Fuad, Istiqomah, and Achmad, "Dialektika Perlindungan Hukum Bagi Guru Dalam Mendisiplinkan Siswa Di Sekolah." 
components (law-making institutions, law enforcement bureaucracy, and role holders) play a role in the legal corridor, while personal and social forces are "non-legal" components.

Furthermore, the four components can be described in the propositions of Robert B. Seidman, as follows: First, every rule of law prescribes how a role occupant is expected to act. (Every legal regulation is according to the rules, and instructs the stakeholders to act and behave).

Second, how a role occupant will act in response to norm of law is function of the rules laid down, their sanctions, the activity of enforcement institutions, and the inherent complex of social, political, and other forces affecting him. (Responses and actions taken by stakeholders are feedback from the function of an applicable regulation. Including sanctions, namely the performance and policies of implementing agencies/regulations and the strategic environment that influence them).

Third, how the enforcement institution, will act in response to norm of law is a function of the rule laid down their sanctions, the inherent complex of social, political, and other process affecting them, and the feedbacks from role occupants. (Actions taken by regulatory implementing agencies in response to legal regulations are a function of the applicable legal regulations and their sanctions and all forces in the strategic environment that affect them, as feedback from stakeholders or who are subject to laws and regulations).

Fourth, how the law maker will act is a function of the rules laid down for their behavior their sanctions, the inherent complex of social, political, ideological, and other forces affecting them, and the feedbacks from role occupants and bureaucracy. (What actions are taken by lawmakers, are also a function of the applicable legal regulations, including the sanctions and the influence of all strategic forces on themselves, as well as feedback that comes from stakeholders, implementers, and implementers of regulations).

The four propositions above clearly describe how a rule of law works in society. Seidman's theory can be used to examine the legal regulations made by state elites, and whether the operation of the law functions properly and is effective in its application in society, or on the contrary it is not working effectively.

\section{Method}

\section{Preliminary activities}

The implementation of this service activity begins with preliminary activities, where at this stage, the Implementation Team identifies more deeply and further the problems faced by partners and the solutions that can 
be offered. Problem identification in this stage is carried out through observation methods and questionnaire surveys to activity participants.

\section{Activity Method}

Activities in this service are carried out with several methods as follows, namely:

\section{1) Workshops and Training}

This activity is carried out to get more tangible results and clear outcomes, so that workshops and training are carried out regularly and continuously. The workshop and training involved several parties, including the Implementing Team, Expert Team, Facilitators, and Participants. The number of workshops and training in activities is planned for 4 (four) times, with details as follows:

\begin{tabular}{|c|c|c|c|}
\hline No & Material & Facilitator & Location \\
\hline 1 & $\begin{array}{l}\text { Introduction to } \\
\text { Legal Assistance } \\
\text { for Teachers and } \\
\text { Students }\end{array}$ & Ridwan Arifin & Mirit PGRI Hall \\
\hline 2 & $\begin{array}{l}\text { Legal Assistance } \\
\text { Techniques for } \\
\text { Teachers and } \\
\text { Students }\end{array}$ & Rasdi & Mirit PGRI Hall \\
\hline 3 & $\begin{array}{l}\text { Multi-Sectoral } \\
\text { Cooperation in } \\
\text { Legal Problem } \\
\text { Resolution }\end{array}$ & $\begin{array}{l}\text { Dwi Bagus } \\
\text { Kurniawan }\end{array}$ & Mirit PGRI Hall \\
\hline 4 & $\begin{array}{l}\text { Legal Counseling } \\
\text { and Consulting } \\
\text { Techniques }\end{array}$ & $\begin{array}{l}\text { Ahsana } \\
\text { Nadiyya }\end{array}$ & Mirit PGRI Hall \\
\hline
\end{tabular}

\section{2) Simulation and Application}

Simulations are carried out to provide experience to partners through direct applications related to legal assistance.

\section{3) Accompaniment}

The mentoring method is carried out to oversee and assist partner participants on a regular basis in achieving the expected output targets. Assistance is carried out in a concrete and applicable manner, where partner participants will be assisted intensively and directly to solve the problems they face.

4) Case study

The case study method will be given to participants as a stimulus for logical, structured, and critical thinking on various problems in legal 
studies. The case studies offered vary according to the needs of partner participants.

\section{Result And Discussion}

\section{Legal Protection for Teachers in Mirit District, Kebumen} Regency

Legal Protection for Teachers, refers to Law Number 14 of 2005 concerning Teachers and Lecturers (Teachers and Lecturers Law). This provision clearly regulates the rights and obligations of teachers in carrying out their professional duties as teachers. Article 14 paragraph (1) of the Law on Teachers and Lecturers emphasizes that in carrying out professional duties, teachers have the right to:

a. earn income above the minimum living needs and social welfare guarantees;

b. get promotions and awards in accordance with their duties and work performance;

c. obtain protection in carrying out their duties and intellectual property rights;

d. get the opportunity to improve competence;

e. obtain and utilize learning facilities and infrastructure to support the smooth running of professional tasks;

f. have the freedom to provide assessments and participate in determining graduation, awards, and/or sanctions to students in accordance with educational rules, teacher code of ethics, and statutory regulations;

g. obtain a sense of security and security guarantees in carrying out their duties;

h. have the freedom to associate in professional organizations;

i. have the opportunity to play a role in the determination of education policy;

j. obtain opportunities to develop and improve academic qualifications and competencies; and/or

k. receive training and professional development in their field.

Further provisions regarding teacher rights are regulated by government regulations. Article 20 of the Law on Teachers and Lecturers explains that in carrying out professional duties, teachers are obliged to:

a. planning learning, implementing quality learning processes, as well as assessing and evaluating learning outcomes; 
b. improve and develop academic qualifications and competencies on an ongoing basis in line with the development of science, technology, and the arts;

c. act objectively and non-discriminatory on the basis of considerations of gender, religion, ethnicity, race, and certain physical conditions, or family background, and socio-economic status of students in learning;

d. uphold the laws and regulations, laws, and teacher code of ethics, as well as religious and ethical values; and

e. maintain and foster national unity and integrity.

Against teachers who violate the obligations above, there is a threat of administrative sanctions to ethics as regulated in the provisions of Article 77 of the Law on Teachers and Lecturers which reads:

1. Teachers who are appointed by the Government or regional governments who do not carry out the obligations as referred to in Article 20 are subject to sanctions in accordance with statutory regulations.

2. The sanctions as referred to in paragraph (1) are in the form of:

a. reprimand;

b. written warning;

c. postponement of granting teacher rights;

d. demotion;

e. honourable dismissal; or

f. dishonourable dismissal.

3. Teachers with official bond status as referred to in Article 22 who do not carry out their duties in accordance with the work agreement or collective work agreement are subject to sanctions in accordance with the official bond agreement.

4. Teachers who are appointed by education providers or educational units organized by the community, who do not carry out the obligations as referred to in Article 20 are subject to sanctions in accordance with the work agreement or collective work agreement.

5. Teachers who violate the code of ethics are subject to sanctions by professional organizations.

6. Teachers who are subject to sanctions as referred to in paragraph (1), paragraph (2), paragraph (3), paragraph (4), and paragraph (5) have the right to defend themselves.

Referring to the above provisions, it is clearly stated that the Law on Teachers and Lecturers provides legal protection for teachers to carry out their professional duties by giving them the right to have the freedom to give evaluation and participate in determining graduation, awards, and/or 
sanctions to students in accordance with educational rules, teacher code of ethics, and laws and regulations and obtain a sense of security and guarantee of safety in carrying out their duties.

However, it is also emphasized that in carrying out their professional duties, teachers are obliged, among other things, to act objectively and nondiscriminatory on the basis of considerations of gender, religion, ethnicity, race, and certain physical conditions, or family background, and socioeconomic status of participants. students in learning and also upholds laws and regulations, laws, and teacher code of ethics, as well as religious and ethical values.

Thus, the freedom given to teachers in giving sanctions to students must be in accordance with the rules of education, the teacher's code of ethics, and laws and regulations.

It is an obligation for teachers to exercise their right to act objectively and non-discriminatory on the basis of considerations of gender, religion, ethnicity, race, and certain physical conditions, or family background, and the socioeconomic status of students in learning and uphold the laws and regulations law, teacher code of ethics, as well as religious and ethical values.

When the rights and obligations of teachers have been carried out in a balanced and responsible manner in accordance with the provisions of the Law on Teachers and Lecturers, it is hoped that there will be no problems that lead to reporting of administrative violations, teacher codes of ethics, to reports of criminal law cases or even threats of sanctions that will be the consequences if proven.

\section{Legal Protection Collaboration for Teachers (Multisectoral Approach)}

The Association of Teachers of the Republic of Indonesia (PGRI) is an association with a legal entity established and managed by teachers as a forum for developing professionalism, fighting for legal protection, and protecting work safety as well as collecting and channelling the aspirations of its members. PGRI has a strategic role in reforming national education for its members, PGRI plays a role and is responsible and fights for efforts to realize and protect the human rights and dignity of teachers, especially in the aspect of their profession and welfare.

As a professional organization, PGRI also wants to unite all teachers and education personnel at all types, levels, and educational units in order to increase service and participation in national development. In this case, PGRI should also be able to establish cooperative relationships with educational institutions, organizations engaged in education, and/or community 
organizations in general in order to improve the quality of education and culture.

The existence of a teacher professional organization is an indispensable professional necessity. The role of protecting and nurturing even when teachers are considered unprofessional in carrying out their profession, it is the professional organizations that must appear earlier to carry out evaluation and verification. Because professional organizations are more competent in conducting evaluation and verification. Professional testing of teachers and other professions is only possible by those who understand and study the profession. It is the professional organization that should foster and protect by using an approach to the code of ethics of the teaching profession. In which there are professional and independent tools that carry out this role, namely the Indonesian Teacher Honorary Council (DKGI) (Harun, 2016).

The Indonesian Teacher Honorary Council (DKGI) is a PGRI organization set up to carry out the task of providing advice, opinions, considerations, assessments, enforcement, and violations of organizational discipline and professional ethics for teachers. The Honour of Indonesian Teachers, in terms of carrying out the duties and authorities of guidance, supervision, and assessment of the Indonesian Teacher Code of Ethics (Harun, 2016). In Article 42 of Law Number 14 of 2005 Article 42, the teacher professional organization has the authority to: a) Establish and enforce a code of ethics for teachers b) Provide legal assistance to teachers c) Provide protection for the teaching profession d) Conduct teacher professional development and development e) Advancing national education. Optimizing the Legal Aid Institute (LBH) under the auspices of PGRI is expected to be one of the solutions in providing protection for teachers who are facing legal problems. The role of teacher professional organizations has an important role to provide protection and development of the teaching profession.

\section{Government Policy on Legal Protection Efforts for the Teacher Profession}

Protection is all efforts aimed at providing a sense of security to victims carried out by the family, advocate, social institutions, police, prosecutors, courts, or other parties, either temporarily or based on court decisions. According to CST Kansil Legal Protection are various legal efforts that must be provided by law enforcement officers to provide a sense of security, both mentally and physically from disturbances and various threats from any party.

Legal protection is very necessary for teachers as educators to protect their rights. In the Criminal Code, the examination of criminal cases must be 
carried out by understanding humans and humanity, whose dignity must be protected. Although the purpose of law enforcement is to defend and protect the interests of the community, law enforcers must not sacrifice the rights and dignity of suspects or defendants. On the other hand, the protection of the dignity of the suspect or defendant must not sacrifice the interests of the community. Law enforcement officers must be able to lay down the principle of balance that has been outlined by the Criminal Procedure Code so as not to sacrifice both interests that must be protected by law.

The rise of various cases that befell teachers in carrying out their professional duties is one proof that legal protection for the teaching profession has not been running properly. Teachers as a noble/respectable profession, like other professions, apparently have not been properly understood by the public in general and especially law enforcement officers who are extensions of the government.

These teachers are usually reported to the police by their parents for violating the Child Protection Law (UUPA). UUPA seems to be holding hostages and a tool to criminalize teachers. The main article that is used as a reference in the report on complaints of violence against children by teachers is Article 54 of Law no. 35 of 2014 concerning Amendments to Law No. 23 of 2002 on Child Protection which states that "Children within and within the education unit are required to receive protection from acts of physical, psychological, sexual violence, and other crimes committed by educators, educational staff, fellow students, and/or other parties. "The types of violence are listed in Article 69, namely physical, psychological, and sexual violence.

The obligation to provide legal protection to teachers in carrying out their professional duties, especially placed on the government, both central and local governments. This obligation begins with providing laws and regulations ranging from Laws, Government Regulations, to Regional Regulations as a legal umbrella for the government and local governments in making policies and forms of policies that are appropriate and in accordance with the rights that teachers must accept.

The central government has enacted Law Number 20 of 2003 concerning the National Education System, Law Number 14 of 2005 concerning Teachers and Lecturers, Government Regulation Number 19 of 2005 concerning National Education Standards and Government Regulation Number 74 of 2008 concerning Teachers. These laws and regulations are the main basis or legal basis for the government in carrying out the obligation to provide legal protection for teachers.

Teachers are normatively protected, as stipulated in Article 14 of Law Number 14 of 2005 letter g "Obtaining a sense of security and guarantee of 
safety in carrying out their duties" and in article 39 of Law Number 14 of 2005. In paragraph 1 " The government, local government, community, professional organizations, and/or educational units are obliged to provide protection to teachers in carrying out their duties. In Paragraph 2 the protection referred to includes legal protection, professional protection, and protection of occupational safety and health. In paragraph 3 , it is explained that legal protection covers acts of violence, threats, discriminatory treatment, intimidation, or unfair treatment on the part of students, parents of students, society, bureaucracy or other parties.

With the issuance of the Minister of Education and Culture Regulation Number 10 of 2017 concerning Protection for Educators and Education Personnel, this is a manifestation of the government's efforts to provide protection to teachers and education personnel in carrying out their duties. Protection obtained by teachers and education personnel includes legal, professional, occupational safety and health protection and intellectual property rights. With this Permendikbud, it will provide more guarantees of protection for educators and education staff who face problems related to the implementation of their duties.

\section{E. Conclusion And Suggestion}

\section{Conclusion}

Education is a conscious and planned effort to create a learning atmosphere and learning process so that students actively develop their potential to have religious spiritual strength, self-control, personality, noble character, and skills needed by themselves, society, nation and state. Without education that is in accordance with national identity, it is impossible that the goals of achieving education will not be fulfilled. As the key to the progress of the nation, one of which is the progress of education owned by the nation.

Teachers have a noble task to help students as facilitators in achieving life goals. Not only in science education but also in moral education. Given that these two things are interrelated with each other in order to achieve a balanced condition between intelligence and behavior carried out. The mandate held by teachers to help shape a better nation's civilization is realized by providing teaching to students in accordance with the competencies possessed by a teacher.

The teacher professional organization is a forum for associations to develop professionalism, fight for legal protection, foster and protect work safety as well as collect and channel the aspirations of its members. Optimizing the organization of the teaching profession has a very important role in realizing the dignity of the teaching profession. The protection of the 
teaching profession is currently regulated in Law Number 14 of 2005 and Regulation of the Minister of Education and Culture Number 10 of 2017. In the current era there are still many acts of violence by students or parents against teachers. The existing regulatory guarantees have not been able to protect teachers from the threat of criminal acts.

\section{Suggestion}

In order to maximize protection for teachers, it is necessary to continue efforts in providing legal assistance and assistance services for teachers involving the Indonesian Teachers Association, Legal Aid Institute, Society, Government, and Universities so as to create a transparent and fair process for teachers, students, and teachers. student parents.

\section{F. Acknowledgments}

None.

\section{G. Declaration of Conflicting Interests}

The authors states that there is no conflict of interest in the publication of this article.

\section{H. Funding}

Universitas Negeri Semarang, Indonesia.

\section{References}

Abdusshomad, Alwazir. "Pengaruh Covid-19 Terhadap Penerapan Pendidikan Karakter Dan Pendidikan Islam." QALAMUNA: Jurnal Pendidikan, Sosial, Dan Agama 12, no. 2 (2020): 107-15. https://doi.org/10.37680/qalamuna.v12i2.407.

Abidin, Zainal. "Perlindungan Hak Asasi Manusia Di Indonesia." Makalah Pelatihan HAM Bagi Panitia RANHAM Prov. Sumatera Barat, Padang, 13 Juni 2013. Jakarta, 2013. https://referensi.elsam.or.id/wpcontent/uploads/2014/09/21.-Perlindungan-Hak-Asasi-Manusia-diIndonesia.pdf.

Afandi, Fachrizal. "Implementasi Pengabdian Masyarakat Berbasis Access To Justice Pada Lembaga Bantuan Hukum Kampus Negeri Pasca Pemberlakuan Undang-Undang Bantuan Hukum." Jurnal Rechts Vinding: Media Pembinaan Hukum Nasional 2, no. 1 (2013): 31. https://doi.org/10.33331/rechtsvinding.v2i1.80.

Akhmaddhian, Suwari. "Bantuan Hukum Bagi Tenaga Pendidik Dan 
Kependidikan Di Desa Mancagar Kabupaten Kuningan, Indonesia.” Empowerment: Jurnal Pengabdian Masyarakat 1, no. 1 (2018): 72-78.

Arifin, R. "Legal Protection and Law Enforcement: The Unfinished Works." Indonesian Journal of Advocacy and Legal Services 2, no. 1 (2020): 1-4. Arifin, Ridwan, Rasdi Rasdi, and Riska Alkadri. "Tinjauan Atas Permasalahan Penegakan Hukum Dan Pemenuhan Hak Dalam Konteks Universalime Dan Relativisme Hak Asasi Manusia Di Indonesia." Jurnal Ilmiah Hukum LEGALITY 26, no. 1 (2018): 17. https://doi.org/10.22219/jihl.v26i1.6612.

Barlian, Ikbal. "Pentingkah Strategi Belajar Mengajar." Jurnal Forum Sosial 6, no. 1 (2013): 241-46.

Basuki, Udiyo. "Perindungan HAM Dalam Negara Hukum Indonesia: Studi Ratifikasi Konvensi Hak-Hak Disabilitas (Convention on The Rights of Persons with Disabilities)." Sosio-Religia 10, no. 1 (2012): 17-34. https://www.aifis-

digilib.com/uploads/1/3/4/6/13465004/revisi_no_02._perlindungan_hak_ asasi_manusia_penulis_udiyo_basuki.pdf.

Dewi, Wahyu Aji Fatma. "Dampak COVID-19 Terhadap Implementasi Pembelajaran Daring Di Sekolah Dasar." Edukatif: Jurnal Ilmu $\begin{array}{lllll}\text { Pendidikan } & 2, & \text { no. } & 1 & \text { (2020): }\end{array}$ https://doi.org/10.31004/edukatif.v2i1.89.

Faqir, Raed SA. "The Philosophy of Punishment: A Study to the History of Classical and Positive Schools of Penology." Forensic Research \& Criminology International Journal 1, no. 6 (2015): 4-11. https://doi.org/10.15406/frcij.2015.01.00035.

Fauzi, Imron. "Dinamika Kekerasan Antara Guru Dan Siswa: Studi Fenomenologi Tentang Resistensi Antara Perlindungan Guru Dan Perlindungan Anak." Tarbiyatuna: Jurnal Pendidikan Islam 10, no. 2 (2017): 40-69.

Fuad, Fokky, Istiqomah Istiqomah, and Suparji Achmad. "Dialektika Perlindungan Hukum Bagi Guru Dalam Mendisiplinkan Siswa Di Sekolah." Indonesian Journal of Law and Policy Studies 1, no. 1 (2020): 55. https://doi.org/10.31000/ijlp.v1i1.2634.

Haris, Hasnawi, and Herman. "Development of a Protection Model for Teachers as Professional Educators in the Indonesian Legal System" 473, no. Icss (2020): https://doi.org/10.2991/assehr.k.201014.164.

Hasima, Rahman. "Perlindungan Hukum Terhadap Guru Dalam Penyelenggaraan Pendidikan Di Kota Kendari.” Jurnal Ilmu Hukum Fakultas Hukum Universitas Riau 9, no. 2 (2020): 190-209. 
Hidayat, Eko. "Perlindungan Hak Asasi Manusia Di Indonesia Dalam Negara Hukum.” ASAS: Jurnal Hukum Ekonomi Syariah 8, no. 2 (2016): 1-8. https://doi.org/https://doi.org/10.24042/asas.v8i2.1249.

Jacob, Brian A. "The Effect of Employment Protection on Teacher Effort." Journal of Labor Economics 31, no. 4 (2013): 727-61. https://doi.org/10.1086/669942.

Jamaluddin, Dindin, Teti Ratnasih, Heri Gunawan, and Epa Paujiah. "Pembelajaran Daring Masa Pandemik Covid-19 Pada Calon Guru: Hambatan, Solusi Dan Proyeksi." Karya Tulis Ilmiah UIN Sunan Gunung Djjati Bandung, 2020, 1-10. http://digilib.uinsgd.ac.id/30518/.

Jimly Asshiddiqie. "Pancasila Dan Empat Pilar Kehidupan Berbangsa," 2019.

Kennedy, Chloë. "Declaring Crimes." Oxford Journal of Legal Studies 37, no. 4 (2017): 741-69. https://doi.org/10.1093/ojls/gqx005.

Komara, Endang. "Perlindungan Profesi Guru Di Indonesia." Mimbar $\begin{array}{lllll}\text { Pendidikan } & 1, & \text { no. } & 2 & \text { (2016): }\end{array}$ https://doi.org/10.17509/mimbardik.v1i2.3938.

Lubis, Muhammad Ikhsan. "The Relationship of International Human Rights Law with International Humanitarian Law in Situations of International Armed Conflicts" 1, no. 01 (2016): 13-34.

Matnuh, Harpani. "Perlindungan Hukum Profesionalisme Guru." Jurnal Pendidikan Kewarganegaraan 7, no. 2 (2017): 46-50.

Muhammad Hashim Kamali. Freedom, Equality And Justice In Islam. Cambridge: The Islamic Text Society, 1999.

Panjaitan, Tri Rezki Andika, Mahzaniar Mahzaniar, and Herlina Hanum. "Tinjauan Yuridis Tentang Perlindungan Hukum Bagi Guru Terkait Tindakan Pemberian Hukuman (Punishment) Terhadap Upaya Mendisiplinkan Siswanya (Studi Kasus SD 117513 Pulo Tarutung)." Prosiding Seminar Nasional Dan Expo Hasil Penelitian Dan Pengabdian Masyarakat 2, no. 1 (2019): 1404-8.

Purba, Nelvitia, Reynaldi Putra Rosihan, Ali Mukti Tanjung, Rudy Pramono, Agus Purwanto, and Mukidi. "Efforts to Protect Violence in the Households during Covid-19 in Indonesia." International Journal of Criminology and Sociology 10 (2021): 548-53.

Ratu, Dian, Ayu Uswatun, and Hascaryo Pramudibyanto. "Pendidikan Dalam Masa Pandemi Covid-19." Jurnal Sinestesia 10, no. 1 (2020): 4148. https://sinestesia.pustaka.my.id/journal/article/view/44.

Rawls. John. A Theory Of Justive. Cambridge: The Belknap Press, 1973.

Sagama, Suwardi. "Analisis Konsep Keadilan, Kepastian Hukum Dan Kemanfaatan Dalam Pengelolaan Lingkungan.” Mazahib 15, no. 1 
(2016): 20-41. https://doi.org/10.21093/mj.v15i1.590.

Sari, Widya, Andi Muhammad Rifki, and Mila Karmila. "Pembelajaran Jarak Jauh Pada Masa Darurat Covid 19.” Jurnal MAPPESONA, no. 1 (2020): 12.

Serah, Yenny Aman, and Rini Setiawati. "Non-Penal Policy Against Teacher Criminalization.” Journal of Critical Reviews 7, no. 14 (2020): 656-60. https://doi.org/10.31838/jcr.07.14.115.

Serah, Yenny, and R Setiawati. "Urgency Formation of Legal Service Institutions and Teacher Protection," 2020, 1-8. https://doi.org/10.4108/eai.26-11-2019.2295209.

Serah, Yenny, and Rini Setiawati. "Fulfillment of Teacher Protection Rights." Annual Program of International Conference on Human Rights 1, no. 1 (2019): 1-10.

Siahaan, Matdio. "Dampak Pandemi Covid-19 Terhadap Dunia Pendidikan." Jurnal Kajian Ilmiah 1, no. 1 (2020): 73-80. https://doi.org/10.31599/jki.v1i1.265.

Sulisworo, Dwi, Rahmad Nasir, and Ika Maryani. "Identification of Teachers' Problems in Indonesia on Facing Global Community." International Journal of Research Studies in Education 6, no. 2 (2016). https://doi.org/10.5861/ijrse.2016.1519.

Triwahyuningsih, Susani. "Perlindungan Dan Penegakan Hak Asasi Manusia (HAM) Di Indonesia." Jurnal Hukum Legal Standing 2, no. 2 (2018): 133-121. https://doi.org/http://dx.doi.org/10.24269/ls.v2i2.1242.

Weis, Lael K. "Constitutional Directive Principles." Oxford Journal of Legal Studies 37, no. 4 (2017): 916-45. https://doi.org/10.1093/ojls/gqx015.

Widarsih, Ria, and Nahiyah Jaidi Faraz. "Evaluasi Kinerja Guru IPS SMP Berdasarkan Standar Kompetensi Guru Di Kabupaten Kebumen.” Harmoni Sosial: Jurnal Pendidikan IPS 3, no. 2 (2016): 177-87. online: http://journal.uny.ac.id/index.php/hsjpi\%0AEVALUASI.

Wilujeng, Sri Rahayu. "Hak Asasi Manusia: Tinjauan Dari Aspek Historis Dan Yuridis.” Jurnal Humanika 18, no. 2 (2013): 162.

\section{ABOUT AUTHOR(S)}

Surip, S.Pd. SD is a Teacher at SDN Tlogodepok Kebumen Indonesia. He also a Chief of Indonesian Teachers Association (Persatuan Guru Republik Indonesia, PGRI) Mirit. Rasdi, S.Pd., M.H is a Lecturer at Department of Criminal Law, Faculty of Law Universitasa Negeri Semarang, He also Doctoral student at Universitas Diponegoro Semarang. Ahsana Nadiyya is a Student at Faculty of Law UNNES. She is an Editor in Chief Lex Scientia Law Review (Undergraduate Law Student Journal). Ridwan Arifin, S.H. LL.M., is a Lecturer at Department of Criminal Law, Faculty of Law Universitasa Negeri Semarang. Dwi Bagus Kurniawan is a Staff at Faculty of Law Universitas Negeri Semarang. 